\title{
AC 2010-378: KNOWLEDGE OF CONTEMPORARY ISSUES HELD BY ENGINEERING STUDENTS
}

\section{Enno Koehn, Lamar University}

Enno "Ed" Koehn is Professor of Civil Engineering at Lamar University. Dr. Koehn has served as the principle investigator for several research and development projects dealing with various aspects of construction. He also has experience in the design, scheduling, and estimating of facilities. He has authored/co-authored over 200 papers in engineering education, as well as the general areas of civil and construction engineering. Dr. Koehn is a member of ASEE, AACE International, ASCE, NSPE, Chi Epsilon, Tau Beta Pi, Sigma Xi, and is a registered Professional Engineer and Surveyor.

\section{Finhasali Chinwala, Lamar University}

Finhasali Chinwala was enrolled in the College of Graduate Studies and the Department of Civil Engineering at Lamar University. He was awarded the Master of Engineering Degree (ME) in 2009.

\section{James Koehn, Chadron State College}

James F. Koehn is an Assistant Professor in the Department of Business and Economics at Chadron State College, Nebraska, where he is also the Director of the Nebraska Business Development Center. Koehn currently serves on the Education Advisory Committee of the Nebraska Board of Public Accountancy. He holds Bachelor of Arts and Master of Accounting degrees from Rice University and earned a Juris Doctor from Baylor University. Koehn has worked for an international accounting firm in both their Houston and New York City offices, and he practiced tax and corporate law in Austin, Texas. Dr. Koehn is a member of the American Institute of Certified Public Accountants, Texas Society of Certified Public Accountants, and the State Bar of Texas. 


\title{
Knowledge of Contemporary Issues Held By Engineering Students
}

\begin{abstract}
The Accreditation Board for Engineering and Technology (ABET) has ruled that students should have a knowledge of contemporary issues. Today, engineering is conducted on a global scale and is becoming very important for the US as well as the whole world. Therefore, every student should pursue knowledge of contemporary and past information regarding various engineering issues.

This paper presents the level of understanding of typical contemporary issues held by the engineering students. The data may be used to compare and measure the level of contemporary issues held by the students of different engineering schools.

This is a detailed study report of an investigation of students at two levels. The findings show quite different perceptions held by graduate and the undergraduate students. Nevertheless, the knowledge of contemporary issues may be less vital for engineers at the beginning of their career than at a later stage of their professional development. This is also mentioned in the analysis section included in the paper.
\end{abstract}

\section{Introduction}

The present educational system was generally developed in 1950s and was suitable for that time. Today, engineering programs should be conducted on a global scale with industrial practice activities heavily required along with team work projects. Therefore, engineering students may be enrolled in programs that need fundamental changes. There also is a need for professionals to make changes in the practice of engineering. The 1986 failure of the space shuttle Challenger has become a classic example, of the conflict between engineers and managers providing the kind of dramatic tension that assists students to remember the facts and issues. It may be stated that design is a timeless endeavor and failure an ageless problem.

In order to introduce the required ABET criteria concerning knowledge of engineering and contemporary issues; the senior seminar was revised to include a section on this subject area. A questionnaire distributed to both graduate and the undergraduate class was designed to measure student perceptions of various engineering and ethical issues. This knowledge of contemporary issues held by engineering students could prove to be beneficial to them as they graduate and become employed by organizations.

\section{Findings}

Tabular results of the study are found in Tables 1 and 2. Different findings are shown below: 
Question No. 1: President Obama wrote a letter during Engineers Week from the White House addressed to all engineers. Roughly, what did it say?

Overview: President Obama requested engineers to assist in making the world a better place to live. Incorrect responses for these questions were: "To continue studies since there are no jobs" and "CEs are needed for work." In this case only $16.7 \%$ of the graduate students and $66 \%$ of undergraduate students answered this question correctly. ${ }^{1}$

Question No. 2: The Stimulus Bill passed by Congress should help civil engineers. What was its approximate funding level?

Overview: The approximate funding amount of the Stimulus Bill passed by Congress is $\$ 787$

Billion. The bill includes an estimated $\$ 130$ billion in spending for construction programs as well as tax incentives that also will give the industry a boost. Only $16.7 \%$ of the gradate students answered this question correctly. On the other side, roughly $78 \%$ of the undergraduate students answered this most important question correctly. Typically, incorrect answers were 27 billion, 100 billion, 8 trillion, 3 trillion, 5 million etc. ${ }^{2}$

Question No. 3: According to a recent study, estimate the average salary offer to civil engineers graduating with a bachelor's degree?

Overview: The average salary offered to civil engineers graduating with a bachelor's degree is approximately $\$ 50,000$. About $16.7 \%$ of the gradate students and $42.8 \%$ of the undergraduate students answered correctly. Incorrect responses were $\$ 32,000$ or $\$ 40,000$. Salary.com states "The median expected salary for a typical new Civil Engineer in the United States is \$53,712". The same results were quoted by payscale.com. ${ }^{3,4}$

Question No. 4: Does the EEOC approve of an English only language requirement for consulting engineers? (Yes or No)

Overview: EEOC does not require an English only language requirement for consulting engineers. It can only be approved in a case such as a hospital operating room. The EEOC views English-only rules as creating an intimating and isolating work atmosphere for minorities. Even so, it recognizes that there are some jobs in which business needs justify the use of one language by all employees. Such needs, however, must truly rise to the level of a business necessity. The EEOC will give special consideration to situations where safety or cooperative job performance requires all employees to communicate efficiently and effectively with one another, i.e. an emergency room at a hospital. About $65 \%$ of the undergraduate students and fifty percent of the graduate students answered this question correctly. ${ }^{5,6}$

Question No. 5: Research findings indicate that engineers are among the most frequent cheaters during their college career. Which group has the highest rate of cheating?

Overview: Research has shown that engineering students are among the most frequent cheaters (82\%), second only to business majors (91\%). No graduate student answered this question correctly and only $61 \%$ of the undergraduate students were correct. ${ }^{7}$

Question No. 6: A national magazine illustrated roughly 13 individuals who are responsible for the economic problems in the U.S. Name one person.

Overview: Time magazine illustrated roughly 13 people who are responsible for the economic problems in the U.S. They include: Alan Greenspan, Angelo Mozilo, Phil Gramm, Chris Cox, 
Hank Paulson, Joe Cassano, Ian McCarthy, Frank Raines, Kathleen Corbet, Dick Fuld, Marion and Herb Sandler and Bill Clinton. Many of the students answered that George W. Bush is one of the persons who were responsible for the economic crisis in the U.S.. Nevertheless, approximately $22 \%$ of the graduate students and $72 \%$ of the undergraduate students answered this question correctly. ${ }^{8}$

Question No. 7: Name one country that is controlled by a dictatorship that limits human rights. Overview: Zimbabwe, Burma, Saudi Arabia, Iran, Eritrea, Turkmenistan, Libya, Pakistan, Cuba, North Korea, Sudan, Iraq, and Afghanistan are the countries which are controlled by a dictatorship. The incorrect answer of many students was "Germany." All undergraduate students and $66.7 \%$ of the graduate students were correct in this case. ${ }^{9}$

Question No. 8: What was the Morrill Act?

Overview: The Morrill Act provided funds to establish engineering schools and agricultural programs. Stephen Ambrose, at this time concluded that under General Thayer, West Point was turning out better engineers than soldiers. By 1860 "nearly all he great public works of the country had been directed by its graduates; and they were the pioneers in the construction of railroads and the great scientific works of the government." Nobody answered this question correctly. ${ }^{10}$

Question No. 9: Walter P. Moore, a Houston consulting firm, won an award for interior design. What other award did the company recently receive?

Overview: Walter P. Moore, a Houston consulting firm, won an award for interior design. This firm was also named the "best firm for civil engineers to work in." No gradate students answered this question correctly. While, $7.6 \%$ of the undergraduate students were correct. ${ }^{11}$

Question No. 10: The U.S. Federal Government does not collect enough taxes to pay for its operation. For the next budget, determine the \% debt.

Overview: The U.S. Federal Government does not collect enough taxes to pay for its operation. For the next budget cycle the debt may be $75 \%$. No one responded correctly and incorrect answers were $7 \%, 10 \%$ and $25 \% .^{12}$

Question No. 11: ASCE has rated the U.S. infrastructure. What is its infrastructure GPA? Overview: The GPA of the U.S. infrastructure is "D", while the GPA for the Texas Infrastructure is "C-." Here, approximately $6 \%$ of the gradate students and $33 \%$ of the undergraduate students were correct. 13

Question No. 12: According to NTSB, why did the I 35-W bridge in Minneapolis collapse? Overview: The bridge in Minneapolis collapsed because the design of the gusset plate. NTSB safety report says "The investigation discovered that the original design process led to a serious error in sizing of some of the gusset plates in the main trusses. Engineers working in the investigation used generally accepted calculation methodologies to determine the stresses in these gusset plates. Their results indicate that some of the gusset plates were undersized and did not provide the margin of safety expected in a properly designed bridge. These undersized gusset plates were found at 8 (of the 112) nodes on the main trusses of the bridge. These gusset plates were roughly half the thickness required." 14 
Question No. 13: Are floods "Act of God" or "Act of Men"?

Overview: Floods are the "Acts of God", but flood losses are largely "Acts of Men." Fifty percent of the graduate students and 56\% of the undergraduate students answered correctly. ${ }^{15}$

Question No. 14: Name the certification level that Shangri la in Southeast Texas received from the U.S. Green Building council.

Overview: Shangri La Park received a "Platinum" certification from the U.S. Green Building council. Roughly $17 \%$ of the graduate students and nearly $37 \%$ of undergraduate students answered this question correctly. ${ }^{16}$

Question No. 15: What material is used to construct the boardwalk at Shangri La?

Overview: The boardwalk is made from recycled plastic and wood at Shangri La Park. Approximately $17 \%$ of the graduate students and $43 \%$ of the undergraduate students were correct. ${ }^{17}$

Question No. 16: An organization has stated that its members should "listen to what science has to offer" and not "ignore scientific reason." Name the organization.

Overview: Roman Catholic Church has stated that its members should "listen to what science has to offer" and not "ignore scientific reason." The incorrect answers included "ASCE". No graduate student was correct, while $17.39 \%$ of the undergraduate students answered this question correctly. ${ }^{18}$

Question No. 17: Define QBS.

Overview: QBS means "Quality based Selection." Approximately 67\% of the graduate students and $45 \%$ of the undergraduate students answered this question correctly. ${ }^{19}$

Question No. 18: Which country owns the most "U.S. Debt"?

Overview: China owns about $24.07 \%$ of the U.S. debt, the most of any country. Approximately $33 \%$ of the graduate students and $61 \%$ of the undergraduate students were correct. ${ }^{20}$

Question No. 19: Halliburton and KBR have agreed to pay $\$ 579$ million in fines. Why? Overview: Halliburton and KBR have agreed to pay $\$ 579$ million in fines related to allegations of foreign bribery, the biggest ever paid by U.S. companies in a foreign corruption case. This involved a joint venture that spent $\$ 182$ million to bribe Nigerian government officials over a 10year period to win more than $\$ 6$ billion in construction contracts. Approximately $11 \%$ of the graduate students and $35 \%$ of the undergraduate students answered this question correctly. ${ }^{21}$

Question No. 20: The American Recovery and Reinvestment Act (Stimulus Bill) allocated \$27.5 billion for a specific Civil Engineers Area. Name that Area.

Overview: The American Recovery and Reinvestment Act (Stimulus Bill) allocated $\$ 27.5$ billion for Roads and Bridges. About $28 \%$ of the graduate students and $48 \%$ of the undergraduate students were correct. ${ }^{22}$ 
Table 1: Results of an Addendum given to 18 Graduate Students in CVEN 6388 Final Exam, Spring 2009

\begin{tabular}{|c|c|c|c|c|c|c|c|}
\hline \multirow[t]{2}{*}{$\begin{array}{l}\text { Question } \\
\text { No }\end{array}$} & \multirow[t]{2}{*}{ Question } & \multicolumn{2}{|c|}{$\begin{array}{l}\text { Total } \\
\text { Persons } \\
\text { Answered }\end{array}$} & \multicolumn{2}{|c|}{$\begin{array}{l}\text { Answered } \\
\text { Correctly } \\
\text { from Persons } \\
\text { answered } \\
\end{array}$} & \multicolumn{2}{|c|}{$\begin{array}{l}\text { Answered } \\
\text { Correctly } \\
\text { from total } \\
\text { Persons }\end{array}$} \\
\hline & & No & $\%$ & No & $\%$ & No & $\%$ \\
\hline 1 & $\begin{array}{l}\text { President Obama wrote a letter } \\
\text { during Engineers Week from the } \\
\text { White House addressed to all } \\
\text { engineers. Roughly, what did it } \\
\text { say. }\end{array}$ & 6 & 33.33 & 3 & 50.00 & 3 & 16.67 \\
\hline 2 & $\begin{array}{l}\text { The Stimulus Bill passed by } \\
\text { Congress should help civil } \\
\text { engineers. What was its } \\
\text { approximate funding level? }\end{array}$ & 13 & 72.22 & 3 & 23.08 & 3 & 16.67 \\
\hline 3 & $\begin{array}{l}\text { According to a recent study, } \\
\text { estimate the average salary offer } \\
\text { to civil engineers graduating with } \\
\text { a bachelor's degree? }\end{array}$ & 15 & 83.33 & 12 & 80.00 & 12 & 66.67 \\
\hline 4 & $\begin{array}{l}\text { Does the EEOC approve of an } \\
\text { English only language } \\
\text { requirement for consulting } \\
\text { engineers? (Yes or No) }\end{array}$ & 17 & 94.44 & 9 & 52.94 & 9 & 50.00 \\
\hline 5 & $\begin{array}{l}\text { Research findings indicate that } \\
\text { engineers are among the most } \\
\text { frequent cheaters during their } \\
\text { college career. Which group has } \\
\text { the highest rate of cheating? }\end{array}$ & 11 & 61.11 & 0 & 0.00 & 0 & 0.00 \\
\hline 6 & $\begin{array}{l}\text { A national magazine illustrated } \\
\text { roughly } 13 \text { individuals who are } \\
\text { responsible for the economic } \\
\text { problems in the U.S.. Name one } \\
\text { person. }\end{array}$ & 11 & 61.11 & 4 & 36.36 & 4 & 22.22 \\
\hline 7 & $\begin{array}{l}\text { Name one country that is } \\
\text { controlled by a dictatorship that } \\
\text { limits human rights. }\end{array}$ & 13 & 72.22 & 12 & 92.31 & 12 & 66.67 \\
\hline 8 & What was the Morrill Act? & 0 & 0.00 & 0 & 0.00 & 0 & 0.00 \\
\hline
\end{tabular}




\begin{tabular}{|c|c|c|c|c|c|c|c|}
\hline 9 & $\begin{array}{l}\text { Walter P. Moore, a Houston } \\
\text { consulting firm, won an award for } \\
\text { interior design. What other award } \\
\text { did the company recently } \\
\text { receive? }\end{array}$ & 5 & 27.78 & 0 & 0.00 & 0 & 0.00 \\
\hline 10 & $\begin{array}{l}\text { The U.S. Federal Government } \\
\text { Does not collect enough taxes pay } \\
\text { for its operation. For the next } \\
\text { budget, determine the } \% \text { debt. }\end{array}$ & 8 & 44.44 & 4 & 50.00 & 4 & 22.22 \\
\hline 11 & $\begin{array}{l}\text { ASCE has rated the U.S. } \\
\text { infrastructure. What is its } \\
\text { infrastructure GPA? }\end{array}$ & 9 & 50.00 & 1 & 11.11 & 1 & 5.56 \\
\hline 12 & $\begin{array}{l}\text { According to NTSB, why did the } \\
\text { I } 35 \text { - W bridge in Minneapolis } \\
\text { collapse? }\end{array}$ & 14 & 77.78 & 10 & 71.43 & 10 & 55.56 \\
\hline 13 & $\begin{array}{l}\text { Are floods "Act of God" or "Act } \\
\text { of Men"? }\end{array}$ & 18 & 100.00 & 9 & 50.00 & 9 & 50.00 \\
\hline 14 & $\begin{array}{l}\text { Name the certification level that } \\
\text { Shangri la in Southeast Texas } \\
\text { received from the U.S. Green } \\
\text { Building council. }\end{array}$ & 3 & 16.67 & 3 & 100.00 & 3 & 16.67 \\
\hline 15 & $\begin{array}{l}\text { What material is used to construct } \\
\text { the boardwalk at Shangri La? }\end{array}$ & 3 & 16.67 & 3 & 100.00 & 3 & 16.67 \\
\hline 16 & $\begin{array}{l}\text { An organization has stated that its } \\
\text { members should "listen to what } \\
\text { science has to offer" and not } \\
\text { "ignore scientific reason". Name } \\
\text { the organization. }\end{array}$ & 2 & 11.11 & 0 & 0.00 & 0 & 0.00 \\
\hline 17 & Define QBS. & 12 & 66.67 & 12 & 100.00 & 12 & \begin{tabular}{|l|}
66.67 \\
\end{tabular} \\
\hline 18 & $\begin{array}{l}\text { Which country owns the most } \\
\text { "U.S. Debt"? }\end{array}$ & 12 & 66.67 & 6 & 50.00 & 6 & 33.33 \\
\hline 19 & $\begin{array}{l}\text { Halliburton and KBR have agreed } \\
\text { to pay } \$ 579 \text { million in fines. } \\
\text { Why? }\end{array}$ & 5 & 27.78 & 2 & 40.00 & 2 & 11.11 \\
\hline
\end{tabular}




\begin{tabular}{|l|l|l|l|l|l|l|l|}
\hline 20 & $\begin{array}{l}\text { The American Recovery and } \\
\text { Reinvestment Sect (Stimulus Bill) } \\
\text { allocated \$27.5 billion for a } \\
\text { specific Civil Engineers Area. } \\
\text { Name that Area. }\end{array}$ & 10 & 55.56 & 5 & 50.00 & 5 & 27.78 \\
\hline
\end{tabular}

Table 2 - Results of an Addendum given to 23 Undergraduate Students in CVEN 6388 Final Exam, Spring 2009

\begin{tabular}{|c|c|c|c|c|c|c|c|}
\hline \multirow[t]{2}{*}{$\begin{array}{l}\text { Question } \\
\text { No }\end{array}$} & \multirow[t]{2}{*}{ Question } & \multicolumn{2}{|c|}{\begin{tabular}{|l|} 
Total \\
Persons \\
Answered
\end{tabular}} & \multicolumn{2}{|c|}{$\begin{array}{l}\text { Answered } \\
\text { Correctly } \\
\text { from Persons } \\
\text { answered }\end{array}$} & \multicolumn{2}{|c|}{$\begin{array}{l}\text { Answered } \\
\text { Correctly } \\
\text { from total } \\
\text { Persons }\end{array}$} \\
\hline & & No & $\%$ & No & $\%$ & No & $\%$ \\
\hline 1 & $\begin{array}{l}\text { President Obama wrote a letter } \\
\text { during Engineers Week from the } \\
\text { White House addressed to all } \\
\text { engineers. Roughly, what did it } \\
\text { say? }\end{array}$ & 18 & 78.26 & 12 & 66.67 & 12 & 52.17 \\
\hline 2 & $\begin{array}{l}\text { The Stimulus Bill passed by } \\
\text { Congress should help civil } \\
\text { engineers. What was its } \\
\text { approximate funding level? }\end{array}$ & 21 & 91.30 & 9 & 42.86 & 9 & 39.13 \\
\hline 3 & $\begin{array}{l}\text { According to a recent study, } \\
\text { estimate the average salary offer } \\
\text { to civil engineers graduating with } \\
\text { a bachelor's degree? }\end{array}$ & 23 & 100.00 & 18 & 78.26 & 18 & 78.26 \\
\hline 4 & $\begin{array}{l}\text { Does the EEOC approve of an } \\
\text { English only language } \\
\text { requirement for consulting } \\
\text { engineers? (Yes or No) }\end{array}$ & 23 & 100.00 & 15 & 65.22 & 15 & 65.22 \\
\hline 5 & $\begin{array}{l}\text { Research findings indicate that } \\
\text { engineers are among the most } \\
\text { frequent cheaters during their } \\
\text { college career. Which group has } \\
\text { the highest rate of cheating? }\end{array}$ & 23 & 100.00 & 14 & 60.87 & 14 & 60.87 \\
\hline 6 & $\begin{array}{l}\text { A national magazine illustrated } \\
\text { roughly } 13 \text { individuals who are } \\
\text { responsible for the economic } \\
\text { problems in the U.S.. Name one } \\
\text { person. }\end{array}$ & 21 & 91.30 & 15 & 71.43 & 15 & 65.22 \\
\hline 7 & $\begin{array}{l}\text { Name one country that is } \\
\text { controlled by a dictatorship that } \\
\text { limits human rights. }\end{array}$ & 21 & 91.30 & 21 & 100.00 & 21 & 91.30 \\
\hline
\end{tabular}




\begin{tabular}{|c|c|c|c|c|c|c|c|}
\hline 8 & What was the Morrill Act? & 2 & 8.70 & 0 & 0.00 & 0 & 0.00 \\
\hline 9 & $\begin{array}{l}\text { Walter P. Moore, a Houston } \\
\text { consulting firm, won an award for } \\
\text { interior design. What other award } \\
\text { did the company recently } \\
\text { receive? }\end{array}$ & 13 & 56.52 & 1 & 7.69 & 1 & 4.35 \\
\hline 10 & $\begin{array}{l}\text { The U.S. Federal Government } \\
\text { Does not collect enough taxes pay } \\
\text { for its operation. For the next } \\
\text { budget, determine the \% debt. }\end{array}$ & 18 & 78.26 & 4 & 22.22 & 4 & 17.39 \\
\hline 11 & $\begin{array}{l}\text { ASCE has rated the U.S. } \\
\text { infrastructure. What is its } \\
\text { infrastructure GPA? }\end{array}$ & 21 & 91.30 & 7 & 33.33 & 7 & 30.43 \\
\hline 12 & $\begin{array}{l}\text { According to NTSB, why did the } \\
\text { I } 35 \text { - W bridge in Minneapolis } \\
\text { collapse? }\end{array}$ & 21 & 91.30 & 12 & 57.14 & 12 & 52.17 \\
\hline 13 & $\begin{array}{l}\text { Are floods "Act of God" or "Act } \\
\text { of Men"? }\end{array}$ & 23 & 100.00 & 6 & 26.09 & 6 & 26.09 \\
\hline 14 & $\begin{array}{l}\text { Name the certification level that } \\
\text { Shangri la in Southeast Texas } \\
\text { received from the U.S. Green } \\
\text { Building council. }\end{array}$ & 17 & 73.91 & 12 & 70.59 & 12 & 52.17 \\
\hline 15 & $\begin{array}{l}\text { What material is used to construct } \\
\text { the boardwalk at Shangri La? }\end{array}$ & 18 & 78.26 & 10 & 55.56 & 10 & 43.48 \\
\hline 16 & $\begin{array}{l}\text { An organization has stated that its } \\
\text { members should "listen to what } \\
\text { science has to offer" and not } \\
\text { "ignore scientific reason". Name } \\
\text { the organization. }\end{array}$ & 11 & 47.83 & 4 & 36.36 & 4 & 17.39 \\
\hline 17 & Define QBS. & 9 & 39.13 & 4 & 44.44 & 4 & 17.39 \\
\hline 18 & $\begin{array}{l}\text { Which country owns the most } \\
\text { "U.S. Debt"? }\end{array}$ & 18 & 78.26 & 14 & 77.78 & 14 & 60.87 \\
\hline
\end{tabular}




\begin{tabular}{|l|l|l|l|l|l|l|l|}
\hline 19 & $\begin{array}{l}\text { Halliburton and KBR have agreed } \\
\text { to pay \$579 million in fines. } \\
\text { Why? }\end{array}$ & 17 & 73.91 & 8 & 47.06 & 8 & 34.78 \\
\hline 20 & $\begin{array}{l}\text { The American Recovery and } \\
\text { Reinvestment Sect (Stimulus Bill) } \\
\text { allocated \$27.5 billion for a } \\
\text { specific Civil Engineers Area. } \\
\text { Name that Area. }\end{array}$ & 20 & 86.96 & 11 & 55.00 & 11 & 47.83 \\
\hline
\end{tabular}

Table 3

\begin{tabular}{|c|c|c|c|c|}
\hline & Graduate & Undergraduate & & \\
\hline Q. No & $\begin{array}{l}\% \text { of Students Answered } \\
\text { Correctly from Total } \\
\text { Students (18) }\end{array}$ & $\begin{array}{l}\% \text { of Students Answered } \\
\text { Correctly from Total } \\
\text { Students (23) }\end{array}$ & \multicolumn{2}{|c|}{$\begin{array}{l}\text { Who are ahead for } \\
\text { the particular } \\
\text { question? }\end{array}$} \\
\hline 1 & 16.67 & 52.17 & & UG \\
\hline 2 & 16.67 & 39.13 & & UG \\
\hline 3 & 66.67 & 78.26 & & UG \\
\hline 4 & 50.00 & 65.22 & & UG \\
\hline 5 & 0.00 & 60.87 & & UG \\
\hline 6 & 22.22 & 65.22 & & UG \\
\hline 7 & 66.67 & 91.30 & & UG \\
\hline 8 & 0.00 & 0.00 & & UG \\
\hline 9 & 0.00 & 4.35 & & UG \\
\hline 10 & 22.22 & 17.39 & $\mathrm{G}$ & \\
\hline 11 & 5.56 & 30.43 & & UG \\
\hline 12 & 55.56 & 52.17 & $\mathrm{G}$ & \\
\hline 13 & 50.00 & 26.09 & $\mathrm{G}$ & \\
\hline 14 & 16.67 & 52.17 & & UG \\
\hline
\end{tabular}




\begin{tabular}{|l|l|l|l|l|}
15 & 16.67 & 43.48 & & UG \\
\hline 16 & 0.00 & 17.39 & & UG \\
\hline 17 & 66.67 & 17.39 & G & \\
\hline 18 & 33.33 & 60.87 & & UG \\
\hline 19 & 11.11 & 34.78 & & UG \\
\hline 20 & 27.78 & 47.83 & & UG \\
\hline
\end{tabular}

Table 4

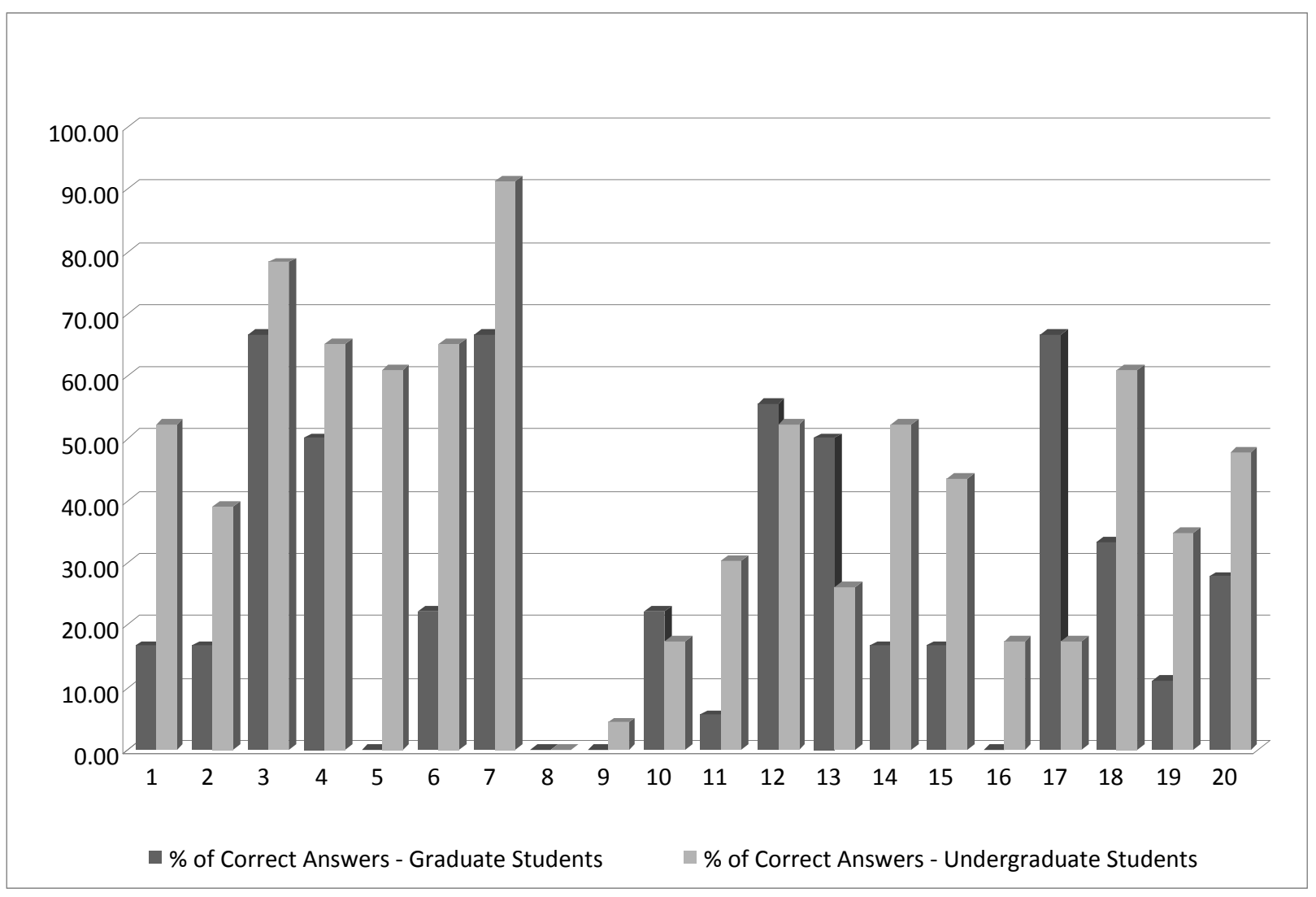

\section{Analysis}

The findings in this paper were based upon the responses of 18 undergraduate and 23 graduate students. The numbers were such that it was deemed unrealistic to conduct an exhaustive statistical analysis of the results. Nevertheless, it appears that engineering students who answered 
the questionnaire do not have, overall, a good knowledge of contemporary issues. This is not surprising since similar findings have been found at other institutions.

Engineering students tend to be hired, after they complete their studies, by organizations that want them to solve specific problems. This continues for numerous years after graduation. Personal knowledge of contemporary issues may not be important at this stage of their career. At a later date knowledge of contemporary issues may be vital for further professional development.

\section{Table 5}

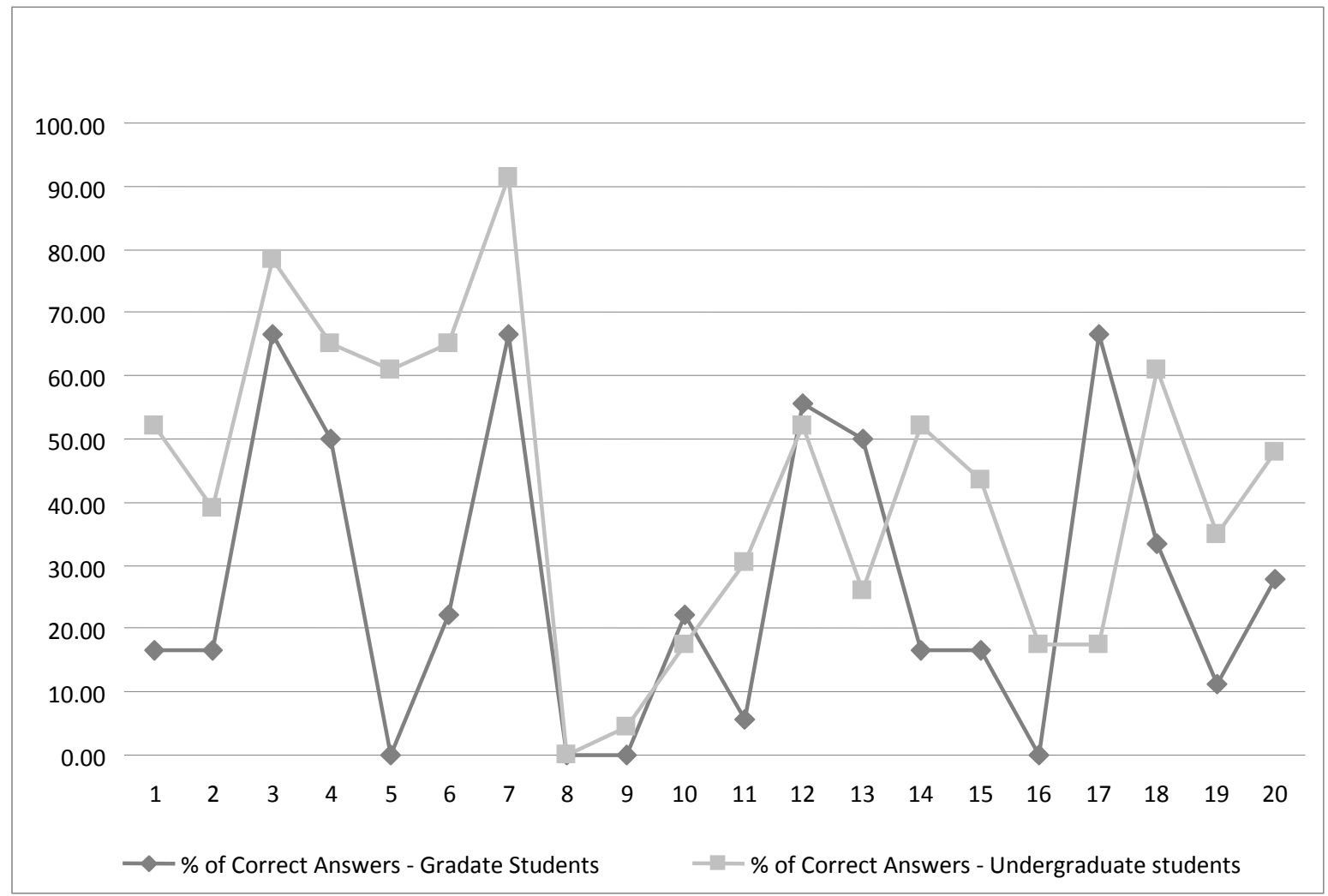

Summary and Conclusion

In the department of Civil Engineering most of the graduate students are international in nature. Some of them are aware of engineering issues which are significant for society and the field of engineering. But, on the other side, some students are completely unaware of contemporary issues. In this survey, the score of the graduate students is generally lower than the undergraduate students which indicate that undergraduate students are more aware of these issues. This concept is illustrated in the Tables 3-5.

Undergraduate students did well compare to the graduate students. In this study undergraduate students seem more aware of contemporary issues. However, professors might have discussed these issues in the undergraduate class and this might be the reason why undergraduate students have higher scores. 
Nevertheless, the findings illustrated in Table 3 show that undergraduates scored at a higher level in 16 of the 20 questions under considerations.

\section{Bibliography}

[1] www.whitehouse.gov (Accessed on $31 \mathrm{Jul} 2009$ )

[2] www.usatoday.com/money (Accessed on 06 Aug 2009)

[3] www.salary.com (Accessed on $31 \mathrm{Jul} 2009)$

[4] www.payscale.com (Accessed on $31 \mathrm{Jul} 2009$ )

[5] www.eeoc.gov (Accessed on 31 Jul 2009)

[6] "English only" by Melissa M. Hensley on www.executivelegaladviser.com

[7] www.prism-magazine.org (Accessed on 31 Jul 2009)

[8] www.time.com (Accessed on 31 Jul 2009)

[9] www.parade.com (Accessed on 31 Jul 2009)

[10] The Bent of TAU BETA PI, Spring 2009

[11] www.enr.com (Accessed on 31 Jul 2009)

[12] www.federalbudget.com (Accessed on 06 Aug 2009)

[13] www.asce.org (Accessed on $31 \mathrm{Jul}$ 2009)

[14] www.ntsb.gov (Accessed on 31 Jul 2009)

[15] August 2007 issue, National Geographic Magazine

[16] www.starkfoundation.org (Accessed on 06 Aug 2009)

[17] www.shangrilagardens.org (Accessed on 06 Aug 2009)

[18] www.8bm.com/diatribes/volume02/038/772.html (Accessed on 06 Aug 2009)

[19] Oct 2006, Vol 28 No. 8, The Magazine For Professional Engineers

[20] http://en.wikipedia.org/wiki/United_States_public_debt (Accessed on 06 Aug 2009)

[21] The Washington Post (2/12, D1, Goldfarb)

[22] February 13, 2009, The Magazine For Professional Engineers

\section{Acknowledgement}

The authors wish to recognize Ms. Linda Dousay for her assistance with the production activities involved in preparing this paper. 